\title{
ANALISA KEPATUHAN MINUM OBAT ANTIHIPERTENSI PADA PASIEN DEWASA POLI PENYAKIT DALAM DI RSUD KARAWANG \\ ${ }^{1}$ Maya Arfania, ${ }^{2}$ Raden NengYuni Budiarti
}

${ }^{1}$ Program Studi Farmasi, Fakultas Teknologi dan Ilmu Komputer, Universitas Buana Perjuangan Karawang (maya.arfania@ubpkarawang.ac.id)

${ }^{2}$ Program Studi Farmasi, Fakultas Teknologi dan Ilmu Komputer, Universitas Buana Perjuangan Karawang (Fm15.radenyuni@ mhs.ubpkarawang.ac.id)

\begin{abstract}
ABSTRAK
Hipertensi merupakan penyakit kronis yang memerlukan terapi. Adanya beberapa hal yang menyebabkan terjadinya penyakit hipertensi, diantaranya usia, tidak dapat mengendalikan stress, kualitas pelayanan kesehatan, polifarmasi. Salah satu penentu keberhasilan terapi adalah adanya kepatuhan minum obat pada pasien. Tujuan penelitian ini adalah untuk melihat gambaran tingkat kepatuhan minum obat antihipertensi pada pasien dewasa dan hubungan antara faktor risiko dengan jenis kelamin dan polifarmasi di RSUD Karawang. Penelitian ini merupakan penelitian Analitik dengan desain cross sectional dimana sampel diambil dengan teknik Purposive Random Sampling. Dari 115 resep yang diperoleh selama penelitian, terdapat 31 pasien $(27 \%)$ laki-laki dan 84 pasien $(73 \%)$ perempuan. Setelah dilakukan wawancara menggunakan kuesioner MMAS-8, didapatkan hasil sebanyak $(22,6 \%)$ patuh dan $(77,4 \%)$ pasien dewasa tidak patuh. Dari hasil analisis berdasarkan uji $C h i$ Square dapat disimpulkan Jenis Kelamin $(p=0,317)$ dan Polifarmasi $(p=0,459)$ bukan fakor resiko terhadap ketidakpatuhan minum obat hipertensi pada pasien dewasa.
\end{abstract}

Kata Kunci: Hipertensi, Tingkat Kepatuhan, Faktor Resiko

\begin{abstract}
The hypertension is a chronic disease that needs to be treated properly and continuously. There are several things that cause hypertension disease, age, can not control the stress, quality of health services, polypharmacy. One of the critical success of therapy is medication compliance by patients. The purpose of this research is to see an overview the compliance level of adult patient's anti-hypertention and the relationship between risk factors at gender and polypharmacy at RSUD Karawang. This is a analysis research with cross sectional where sample were taken by purposive random sampling technique. From 115 prescriptions, there were 31 male (27\%) Patients and 84 female (73\%) patients. After the interview using MMAS-8 questionnare, there were $(22,6 \%)$ compliance and $(77,4 \%)$ uncompliance adult patient. From the results of the analysis based on Chi Square test, it can be concluded that Gender $(p=0,317)$ and Polypharmacy $(p=0,459)$ is not a risk factor for uncompliance in taking hypertension medication in Adult patients.
\end{abstract}

Keywords: Hipertensi, Compliance, Risk Factor 


\section{PENDAHULUAN}

Prevalensi hipertensi di dunia menunjukkan adanya peningkatan pertahunnya. Menurut World Health Organization (WHO) di tahun 2013 menjelaskan bahwa sekitar 9,4 juta kematian di seluruh dunia setiap tahunnya diakibatkan oleh hipertensi, sekitar $40 \%$ orang dewasa berusia 25 tahun ke atas di seluruh dunia pada tahun 2008 didiagnosis hipertensi, diprediksikan pada tahun 2025 kasus hipertensi akan mencapai 1,56 miliar kasus. Menurut Riskesdas, (2013) menunjukkan prevalensi hipertensi di Indonesia yaitu sebesar 26,5\%, dengan prevalensi provinsi Jawa Barat berada diperingkat keempat 29,4\%.. Kemenkes RI, (2016) melakukan (Sirkesnas) diperoleh data bahwa prevalensi penyakit hipertensi di Indonesia telah meningkat menjadi sebesar 32,4\%, dari prevalensi diatas menyatakan bahwa keberhasilan terapi hipertensi dipengaruhi oleh kepatuhan pada terapi.

Berdasarkan hasil demografi Sinuraya dkk (2018) Prevalensi hipertensi di Jawa Barat pada kelompok usia < 40 tahun (5,3\%), usia 40-49 tahun (9,7\%), usia 50-59 tahun (31\%), usia 60-69 tahun (35\%), > 70 tahun (19\%) dengan perbandingan kepatuhan lebih besar pada perempuan $(53,1 \%)$, laki-laki $(46,9 \%)$, hasil penelitian ini menunjukkan bahwa sebanyak 53,.5\% dari responden memiliki tingkat kepatuhan rendah, 32,3\% dari responden memiliki tingkat kepatuhan sedang, 14,2\% dari responden memiliki tingkat kepatuhan tinggi.

Menurut Wibawa, (2008) Faktor risiko kejadian hipertensi yang mempengaruhi pasien tidak patuh dalam pengobatan adalah usia pasien, biaya pengobatan yang mahal, tidak dapat mengendalikan stress, kualitas pelayanan kesehatan, dan penggunaan obat dalam jumlah banyak atau polifarmasi. Menurut Bushardt RL dkk, (2008) Polifarmasi adalah peresepan jumlah obat 6 atau lebih macam obat. Tujuan penelitian ini untuk mengetahui tingkat kepatuhan pasien minum obat dengan cara melakukan uji Kuesioner Moriskey Medication Adherence Scale (MMAS-8).

\section{METODE PENELITIAN}

\section{Rancangan Penelitian}

Penelitian ini merupakan penelitian Analitik dengan menggunakan metode cross sectional dan pengambilan data secara prospective. Pengambilan sampel menggunakan teknik Purposive Random Sampling Pengumpulan sampel berasal dari data primer dengan mengobservasi data hasil kuesioner MMAS-8 kepatuhan minum 
obat yang memenuhi kriteria inklusi usia 18-60 tahun . Jumlah subjek penelitian yang digunakan dihitung berdasarkan rumus persoalan atau satu sampel" (Lemeshow and David, 1997), yaitu :

$$
\mathrm{n}=\mathrm{za} 2 \mathrm{x} \mathrm{p}(1-\mathrm{p}) \mathrm{d}^{2}
$$

Keterangan :

$\mathrm{Za}$ : derivat baku alfa

$\mathrm{P} \quad$ : proporsi variabel yang diteliti

d : presisi

n : jumlah sampel

Pada penelitian ini ditetapkan nilai $\mathfrak{a}$ sebesar 5\% sehingga nilai $\mathrm{Za}=1,96$ dengan nilai presisi (d) sebesar 10\%”. Berdasarkan penelitian sebelumnya yang dilakukan oleh Sinuraya dkk, (2018) "diketahui nilai prevalensi tingkat kepatuhan rendah pada pasien dewasa 53\%". Dengan demikian besar sampel minimal yang terhitung adalah 95 sampel pasien. pasien yang diwawancarai adalah 115 pasien memenuhi dan meminimalisir adanya tingkat kesalahan pada analisa tingkat kepatuhan pasien minum obat.

\section{Alat dan Bahan}

lembar resep hasil pemeriksaan di RSUD Karawang. untuk mengetahui tingkat kepatuhan minum obat pasien hipertensi digunakan kuesioner MMAS-8 (Morisky Medication Adherence Scale).

\section{Analisis data}

Melihat tingkat kepatuhan dengan analisis kuesioner Morisky Medication Adherence Scale (MMAS-8) dan Hubungan faktor resiko dengan kepatuhan dengan analisis chiSquer.

\section{HASIL DAN PEMBAHASAN}

Sampel penelitian sebanyak 115 pasien. Pengambilan sampel menggunakan teknik Purposive Random Sampling dimana untuk melihat gambaran tingkat kepatuhan minum obat antihipertensi pada pasien dewasa di Poli Penyakit Dalam RSUD Karawang menggunakan kuesioner Morisky Medication Adherence Scale (MMAS-8) versi Indonesia yang telah diuji validasi dan reliabilitas. Uji validasi dilakukan kepada 
25 responden dengan menunjukkan hasil yang valid untuk setiap item pertanyaan r>0,39 dengan nilai Croanbach alpha sebesar 0,760.

\begin{tabular}{ccc} 
Tabel 4.2 Karakteristik Pasien Hipertensi di RSUD Karawang \\
\hline Karakteristik & $\begin{array}{c}\text { Frekuensi } \\
\mathrm{N}=(115)\end{array}$ & Persentase\% \\
\hline
\end{tabular}

\section{Jenis Kelamin}

Laki-laki

Perempuan

Usia

$\begin{array}{lcc}18-40 \text { tahun } & 10 & 8,7 \% \\ 41-60 \text { tahun } & 105 & 91,3 \%\end{array}$

\section{Lama Menderita Hipertensi}

1 tahun

2-3 tahun

20

$17,4 \%$

$>3$ tahun

$42 \quad 46,1 \%$

$53 \quad 36,5 \%$

\section{Polifarmasi}

$<5$ Jenis obat

$>5$ Obat

86

$74,8 \%$

$29 \quad 25,2 \%$

Berdasarkan hasil penelitian dapat dilihat pasien yang menderita penyakit hipertensi lebih banyak adalah perempuan dengan jumlah 84 pasien (73\%) dengan usia 41-60 tahun sebanyak 105 pasien (91,3\%). Pasien hipertensi dengan lama menderita sakit $\geq$ 3 tahun sebanyak 53 pasien $(36,5 \%)$ dan rata-rata pasien yang berobat hipertensi dengan resep obat non polifarmasi memiliki jumlah yang lebih banyak yaitu 86 pasien atau $74,5 \%$.

\section{Tabel.4.3 Tingkat Kepatuhan Pasien}

\section{Tingkat Kepatuhan}

Karakteristik

$$
\text { Patuh }(n=26)(22,6 \%) \quad \begin{gathered}
\text { Tidak Patuh } \\
(n=89)(77,4 \%)
\end{gathered} \text { Nilai } p
$$

\section{Jenis Kelamin}

Laki-laki

Perempuan

$7(29,0 \%)$

$24(71,0 \%)$

Polifarmasi

$19(20,2 \%)$

$65(79,8)$

0,317

$\geq 5$ Jenis obat

$$
8(27,6)
$$

$21(72,4)$

$<5$ obat

$18(20,9)$

$68(79,1)$

0,459 
Berdasarkan diagram diatas dapat dilihat tingkat kepatuhan pasien dikategorikan menjadi 2 kategori yaitu kategori patuh dan tidak patuh. Jumlah pasien yang patuh sebanyak 26 pasien $(22,6 \%)$ dan yang tidak patuh sebanyak 89 pasien $(77,4 \%)$. Data yang diperoleh menunjukkan angka ketidakpatuhan lebih tinggi dibandingkan dengan angka kepatuhan. Kategori patuh pada jenis kelamin laki-laki sebanyak 7 pasien (29\%) dan perempuan sebanyak 19 pasien $(20,2 \%)$. Sedangkan untuk kategori tidak patuh pada laki-laki sebanyak 24 pasien $(71 \%)$ dan perempuan sebanyak 65 pasien (79,8\%). Hasil analisa Chi-Square telah didapatkan dengan nilai $p$ sebesar 0,317 $(p>0,05)$, hal ini sejalan dengan hasil penelitian yang dilakukan oleh Pujasari dkk (2015) dengan nilai $p$ sebesar 0,396 ( $p>0,05)$, pada tingkat kepatuhan pasien kategori patuh polifarmasi $(>5)$ sebanyak 8 pasien $(27,6 \%)$ dan non polifarmasi $(<5)$ sebanyak 18 pasien $(20,9 \%)$. Sedangkan untuk kategori tidak patuh pada polifarmasi (> 5) sebanyak 21 pasien $(72,4 \%)$ dan non polifarmasi $(<5)$ sebanyak 68 pasien $(79,1 \%)$. Hasil analisa Chi-Square didapatkan nilai $p$ sebesar 0,459 $(P>0,05)$, hal ini sejalan dengan hasil penelitian yang dilakukan oleh Dewi dkk (2014) dengan nilai $p$ sebesar 1,000 $(P>0,05)$ ". Hal ini dapat disimpulkan bahwa jenis kelamin dan polifarmasi bukanlah faktor resiko ketidakpatuhuan.

\section{KESIMPULAN}

Tingkat kepatuhan yaitu patuh sebanyak 26 pasien $(22,6 \%)$ pasien yang tidak patuh sebanyak 89 pasien $(77,4 \%)$ dengan jumlah terbanyak terdapat pada jenis kelamin perempuan sebanyak 65 pasien $(79,8 \%)$. Pada hasil analisis uji Chi-Square dari penelitian ini menunjukkan bahwa jenis kelamin bukanlah faktor resiko ketidakpatuhuan dengan nilai p sebesar 0,317 ( $\mathrm{P}>0,05)$ dan menunjukkan bahwa polifarmasi bukanlah faktor resiko ketidakpatuhuan dengan nilai $\mathrm{p}$ sebesar 0,459 (P $>0,05)$.

\section{DAFTAR PUSTAKA}

Aditama TY. 2011. Hipertensi: Diagnosis,terapi, Pencegahan dan masalahnya .Edisi 3. UI Press. Jakarta.

Bushardt RL, Massey EB, Simpson TW, Ariail JC, Simpson KN. Polypharmacy: misleading, but manageable. Clin Interventions Aging. 2008;3(2):383-9.

Cristiana A. K. Dewi, dkk. 2014., Drug Therapy Problems Pada Pasien Yang Menerima Resep Polifarmasi. Universitas Airlangga. Volume 1. Nomor 1. Hal 17-22. 
Coylewright M, Keith C. Ferdinand, MD, 2008, Clinical Professor, Cardiology Division Emory University Chief Science Officer Association of Black Cardiologists, Inc. Atlanta, GA2008, Assessment of Cardiovascular Risk Factors in Postmenopausal Women, 51:952

Depkes, 2008.10 Penyakit MenonjolKota ManadoManado.http://typecat.com/pdf/pen gawas-minum-obat.html. diakses pada tanggal jum'at 10/08/2018, 19:56

Depkes RI. 2009. Kategori Umur. http://ilmu-kesehatanmasyarakat.com/2012/05/kategori-umur.html. diakses pada tanggal jum'at 10/08/2018, 19:56

DiPiro, Joseph T., Robert L. Talbert, Gary C. Yee, Gary R. Matzke, Barbara G. Wells, dan L. Michael Posey. 2008. Pharmacotherapy : A Pathophysiologic Approach, 7th Edition. The McGraw-Hill Companies, Inc : USA

Kementerian Kesehatan RI. 2015. Profil Kesehatan Indonesia 2014. Jakarta: Kemenkes RI.

Lemeshow, S., David, W .H.J., 1997. Besar Sampel Dalam Penelitian Kesehatan. Gadjahmada University Press, Yogyakarta.

Moriskey., A. B., A., Krousel-Wood, M.A., Ward, H. 2008, Predictive validityof A medication Adherance Measure in an Outpatien Setting, J. Health-Syst. Pharm, 10: 348-54.

Muchid, abdul., et al. 2006. Pharmaceutical Care Untuk Penyakit Hipertensi. Jakarta: Direktorat Bina Farmasi Komunitas dan Klinik Ditjen Bina Kefarmasian dan Alat Kesehatan,Departemen Kesehatan.

Niven.2012. Psikologi kesehatan pengantar untuk perawat dan professional kesehatan lain. Jakarta: EGC.http://www.medscape.com/viewarticle/ 497725.

Notoatmojo Soekidjo. 2003. Pendidikan dan Perilaku Kesehatan. Rineka Cipta. Jakarta.

Pujasari Ajeng, dkk. 2015. Faktor-Faktor Internal Ketidakpatuhan Pengobatan Hipertensi Di Puskesmas Kedungmundu Kota Semarang. Jurnal Kesehatan Masyarakat UNDIP : Vol 3. No 3. ISSN : 2356-3346. Hal : 99-104

Riset Kesehatan Dasar. 2013. Jakarta: Badan Penelitian dan Pengembangan Kesehatan, Kementerian Kesehatan Republik Indonesia.

Sinuraya Rano K, dkk. 2018. Tingkat Kepatuhan Pengobatan Pasien Hipertensi di Fasilitas Kesehatan Tingkat Pertama di Kota Bandung.Jurnal Farmasi Klinik Indonesia : Vol. 7 No. 2 ISSN: 2252-6218 DOI: 10.15416/ijcp.2018.7.2.124. Halaman 124-133

WHO. 2013.A Global Brief On Hypertension: Silent Killer, Global Public Health Crisis. Switzerland. WHO. http://ishworld.com/downloads/pdf/global _ brief_hype rtension.pdf [Sitasi 24 Juni 2018]. 